ISLLAC : Journal of Intensive Studies on Language, Literature, Art, and Culture

Journal homepage : http://journal2.um.ac.id/index.php/jisllac

\title{
A Structuralist Study of the Wayang Suket Puspasarira Malang
}

\author{
Siti Zurinani* \\ Universitas Brawijaya
}

\section{A R T I C L E I N F O}

Keyword:

wayang puspasarira

structuralism

symbol

\begin{abstract}
A B S T R A C T
Wayang is one of the art forms of Javanese society which has been patented as a cultural heritage, specifically as a Masterpiece of the Oral and Intangible Heritage of Humanity, in 2003. As a cultural heritage, wayang contains various elements of art such as visual arts, sound arts, and drama. In addition, wayang also becomes a facility for rituals, amusement, and aesthetic presentation. Moreover, wayang has been used as a "reference for a better life, because it portrays the eternal messages of humanity". The messages develop an awareness of the audience about good and bad things in life. This research describes the structure and representation of Javanese life philosophy in wayang puspasarira. Through this research, wayang puspasarira has a symbolic structure of the moral and cultural values of Javanese society.
\end{abstract}

(c) 2017 ISLLAC Journal. All rights reserved

\section{INTRODUCTION}

As a creation of man, wayang contains knowledge that may be beneficial for humanity. According to Herusatoto (1983:11), wayang contains various elements of art such as visual arts, sound arts, and drama. In addition, wayang also contains the facility for rituals, amusement, and aesthetic presentation (Soedarsono, 2010: 123). Further, according to Nalan (2015), wayang has been made as a "reference for a better life, because it portrays the eternal messages of humanity". The knowledge contained in those messages may guide people to become better, and as such society needs to be aware of the need to preserve the art of wayang in the midst of the flows of modernity.

The development of wayang in Indonesia has comprised many kinds and variations, one of them being wayang rumput (grass wayang). In general, wayang rumput is an imitation of various wayang kulit figures made out of grass (Javanese: suket). In the beginning, wayang suket was used for games; this is affirmed by Zahid and Nuriyanti (2015) that wayang suket was usually made as a tool for games or to deliver the stories of wayang to children in the islands of Java (Zahid and Nuriyanti, 2015). To make this, several blades of grass are plaited and then arranged in the shape of wayang kulit figures. Although wayang suket is more simple compared to other kinds of wayang based on its shape, overall it still possesses a distinct characteristic or commonality, which is its essence for delivering moral values.

As stated by Macaryus (2008:105-106), in communities of a simple society, art has a tendency to be seen as a cultural expression and product that is related to the social system of the people. This opinion is related to art that contains the values and life experiences of certain societies of cultural actors that are realized through aesthetics in artistic behaviors or activities that are developed by the people, followed by a variety of artistic forms or products that can be visibly enjoyed.

Ironically, wayang suket at present is on the brink of extinction. As reported by the online newspaper Kompas, it was stated that wayang suket is included as one of the types of wayang in Indonesia that is almost extinct (http://sains.kompas.com/ read/2013/08/21/ 0933447/75.Jenis.Wayang.Punah). The factor that causes the nearextinction of forms of wayang in Indonesia is believed by Soemarno (1996:50-61) to be because of its stories and lack of interest of society toward the wayang tradition, whether the conservation of its artists or research connected to wayang. As such, one of the aims of this paper is to return the awareness of society toward wayang suket while at the same time preserving it through further study.

\footnotetext{
${ }^{*}$ Corresponding author.

E-mail addresses: zurienani@gmail.com (Siti Zurinani)
}

2597-7385/ @ 2017 ISLLAC Journal. All rights reserved. This is an open access article under the CC BY license (http://creativecommons.org/licenses/BY/4.0/).

95 | ISLLAC : Journal of Intensive Studies on Language, Literature, Art, and Culture 
As the first stage in a study of wayang, this particular study puts more focus on the physical model of wayang suket of the City of Malang, which is more locally well-known by the term of wayang puspasarira. One of the creators of wayang puspasarira in the City of Malang is Samsul Subakri, who is more well-known by the locals by the name Mbah Karjo. By the efforts of Mbah Karjo, this wayang began to be introduced around five years ago by its shows. The name puspasarira comes from the words "puspa", meaning "flower", and "sarira", meaning little figures or dolls (puppets). According to him, initially, puspasarira was used as an accompanying ritual of the ceremony of death in society. In its later development, wayang puspasarira had begun to be abandoned by many as a medium of ritual, but functionally wayang puspasarira instead began to be re-developed by Mbah Karjo as a medium of performing arts, culture, and education.

METHOD

In this research, selecting key resources or informants becomes quite a crucial matter, and as such the resources or informants who are selected are those who are related to the theme of wayang puspasarira. In addition to key informants, the presence of supporting informants also plays a very important role as the verifier of key informants. The selection of supporting informants was done through snowball sampling of the Malang wayang art community, which includes those who appreciate the art of wayang. For data collection, three kinds of possible methods were used, which were participant observation, interviews, and library research.

Observation is a scientific method that is applied in the effort to obtain scientific knowledge of the activities of people in their relationships amongst one another and the problems that they cause (Koentjaraningrat, 1985: 110). The observation was conducted by participation, or by participant observation; in this manner, the observation involves direct participation to analyze all activities of informants. Through the method of participant observation, it is possible to obtain more in-depth data.

The method of data collection through interviews is very much necessary because every research possesses limitations in terms of observations, a part of which is related to the limits of space and time, such as history or differences in spatial position. Interviews were conducted to obtain primary data, which is data obtained directly from research subjects. Primary data can be obtained through data collection procedures and techniques, which may be in the form of interviews, observation, or the use of measuring instruments that are specially and purposefully designed (Azwar, 2005: 7). In this research, interviews were carried out with key informants, who were $M b a h$ Karjo and $M b a h$ Puji, because they were seen as informants who knew the history of wayang puspasarira. This was also done with other informants, comprised of three wayang artists in the City of Malang, who were seen as possessing knowledge related to the problems of and targets to be achieved in this research.

Library research was conducted by searching for data through investigation of literature, including books, articles, scientific research, and other writings that are thought to be supportive of the problems to be studied. The obtained literature data comprised secondary data and were utilized as complements of primary data obtained through interviews and participant observation.

The process of data analysis in this research covered several stages. The first stage was the identification of data and the gathering of both verbal data and visual data, whether obtained through library research, observations, and interviews. The second stage was the classification of data, which was the sorting or grouping of research data which have been identified according to the types and nature of the data or through the coding process. The third stage was selection, which was the elimination of data that was not relevant to the subject of discussion, thus resulting in data relevant to the problems of the research. The fourth stage was an analysis of the data using an approach of structuralism.

This approach sees the phenomenon of culture as a phenomenon that resembles the phenomenon of language. Language formulates explicitly the rules or norms that are implicit in nature (Ahimsa-Putra, 2009: 43). Because of this, the data analysis of this research attempts to relate the story, mythology, wayang formation process, and naming in the anatomy of wayang as something that is explicit in nature of behaviors and faiths in Javanese society, which is implicit in nature. It is through this analysis that the goals of the research, connected with how the structure of wayang puspasarira is and how it represents Javanese culture, can be answered.

\section{RESULTS AND DISCUSSION \\ Wayang Puspasarira as Performing Arts}

Early on, the wayang rumput (wayang suket) usually was used as a tool for games or to deliver stories of wayang to children in the rural parts of Java. Even so, there are people who have the opinion that the Wayang Rumput (Wayang Suket) at its inception was usually created by shepherds at their leisure. When the water buffaloes, cattle, or goats were busy grazing, the bocah angon (shepherds' children) tried to imitate the puppeteers who played wayang, with the grass available around them (http://elib.unikom.ac.id). Over the course of time, wayang suket became quite popular within Javanese society and was considered as one of the anti-mainstream wayang forms from the wayang commonly found in Java. Fundamentally, wayang suket has almost the same formation structure as wayang kulit, though there are several differences that make it unique.

Currently, there are several artists who develop the wayang artistry that is termed as "wayang suket". One of the creators of wayang suket is Samsul Subakri, known by the name Mbah Karjo, who then appeared with his wayang puspasarira, and resides in the City of Malang. The wayang that he names "puspasarira" began to be introduced around 2012. "Puspasarira" comes from the words "puspa", which means "flower", and "sarira", meaning little figures or dolls (puppets). Different from the original functions of typical wayang suket, puspasarira according to him was initially used as a complement of the ritual of the ceremony of death in society as a substitute for a human body. From 
this, wayang puspasarira was understood as a small body (body substitute) made from flowers. Later on, puspasarira began to be developed as a medium of performing arts, culture, and education, tending to leave behind its position as a ritual complement.

Previously it has been mentioned that currently, wayang has many variations; not just made from leather, anything can be used as the material for wayang creation. One of those that have experienced development is wayang made out of suket (grass). Even so, wayang suket itself also turns out to have differences from one region to another, from shape, raw material, to the process of creation. Specifically, wayang puspasarira uses mendong as its basic raw material; mendong is a type of grass that grows mostly on riversides and is often used as the raw material for creating traditional mats. Nowadays, to procure the basic mendong material, Mbah Karjo often does so by purchasing from the Wajak region, and this becomes another distinct feature of wayang puspasarira.

There are several other distinct features of the wayang suket puspasarira form introduced by Mbah Karjo. (1) The weave is smooth, neat, and orderly, the plait is appropriate to the original form of the eyes, nose, bun (gelung), ear ornament (sumping), rings (gelang), and train (kunca). All these parts were made simply by Mbah Karjo in resemblance but each has its own meaning in the names. (2) Overall, the ornaments visualized through the woven grass are appropriate to wayang kulit as their guide, or to the original character. (3) The size of the wayang suket may be adjusted to audience demand.

The story of the creation of wayang puspasarira began in 2001 when Mbah HKarjo started becoming artistic by using wayang to tell stories. At that time, the wayang that Mbah Karjo presented was made from udeng (headband cloth) tied by hand. In later times, Mbah Karjo became creative by using plastic folders and plastic bags as materials to make wayang.

The interest of Mbah Karjo in using suket and in particular mendong for wayang performances began in 2010. At that time, he was asked in an activity to conduct a wayang workshop with 3500 participants using environmentallyfriendly materials. From this activity, Mbah Karjo began to popularize wayang suket in the City of Malang. Even so, according to Mbah Karjo, wayang suket has previously become popular as introduced among others by Mbah Slamet Gundono in Central Java or Surakarta, Mbah Tulip in Purbolinggo, and Mbah Gepuk in Sidoarjo. What differentiates this from prior wayang suket is that the wayang suket developed by Mbah Karjo is named as puspasarira.

The naming of wayang suket as puspasarira by Mbah Karjo was done in 2012; previously, it was named as Dami Sarira, where the word "dami" came from the word "Damen" (straw) yet at that time the wayang suket of Mbah Karjo was made from mendong grass. In the end "wayang puspasarira" was chosen as the name of the wayang suket by Mbah Karjo by the suggestion of Dwi Cahyono, a historian of the State University of Malang (UM).

In the end, wayang puspasarira was chosen by Mbah Karjo as the official name of the wayang suket he developed, and the next step was to perfect the form of the wayang suket using flower elements of mendong to complement the word "puspa", meaning "flower". In addition, what makes wayang suket puspasarira quite distinct from other wayang suket is the performing of the wayang. In every performance conducted by Mbah Karjo, the show always began with the ritual of creating the wayang part by part in the structure of wayang. Mbah Karjo considers this as something that makes his wayang suket distinct from others.

\section{Structure of the Wayang Suket Puspasarira}

According to Mbah Karjo, the process of making the wayang suket contains many philosophical values. This can be seen when Mbah Karjo performs the wayang, which always begins with making the wayang puspasarira while telling the parts of the wayang one by one. "First, the number (of blades of grass that make it up) is three. This is a symbol of the ati (heart), lathi (words), and pakarti (actions)," he said. For the materials used, each mendong were to be cut with a length of 100 "finger segments" or around one meter. The number 100 is taken from Javanese dating, human life, nature, and the process of their creation. According to Mbah Karjo, "values are inherent in its creation." Then, the three blades of grass are each cut into two parts, where the number two symbolizes the two genders of people, male and female, or in Javanese, he calls as "Wulanjono-Wulanjani". The cut in the middle divides the blades of grass into six parts, and from these six parts, the wayang puspasarira is assembled.

The first stage in starting the plaiting process is making the nose. According to him, the nose is a sign of life. The plaiting continues by making the eyes, the head, and then the hair. This proceeds into the shoulder. Afterwards, the process continues to the arms, then the chest, and ends with the feet.

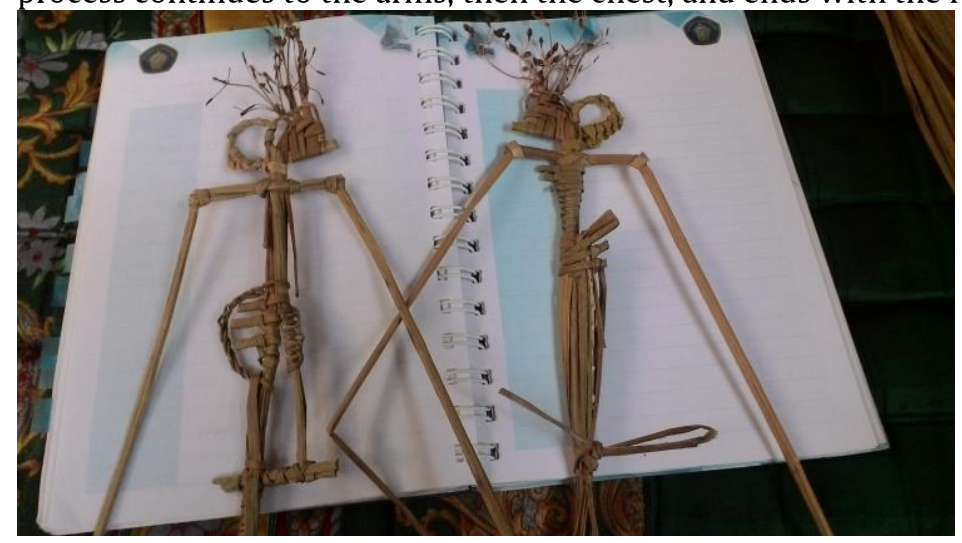

97 | ISLLAC : Journal of Intensive Studies on Language, Literature, Art, and Culture 
Figure 1. Structure of the wayang (left, male; right, female)

The character and structure of the wayang puspasarira are differentiated into two, as the structure of the male wayang and the structure of the female wayang. In the process of creating the wayang puspasarira, every assembled part contains philosophical meanings. The structures of the male and female wayang are explained in the following tables.

Table 1. Structure of the Wayang: Male

\begin{tabular}{|c|c|c|}
\hline Body Form & Symbol & Interpretation \\
\hline $\begin{array}{l}\text { Isine Wewarah } \\
\text { Katarik ing Sukmo }\end{array}$ & $\begin{array}{l}\text { Head } \\
\text { Hair, Bun, Flower }\end{array}$ & $\begin{array}{l}\text { Concentration in reverence - as a rule, living people } \\
\text { will breathe, and those that cannot breathe will die. } \\
\text { Intellect guides people in their actions. This idea leads } \\
\text { to norms and values in society. } \\
\text { Beauty, fragrance, grandeur, elegance, wisdom }\end{array}$ \\
\hline $\begin{array}{l}\text { Ojo Ngugu yen seneng di } \\
\text { lulu } \\
\text { Pujimu ojo mung }\end{array}$ & $\begin{array}{l}\text { Back to the neck } \\
\text { Shoulder }\end{array}$ & $\begin{array}{l}\text { Introspection } \\
\text { Gratefulness for the blessings of God } \\
\text { Self-introspection - people have good and bad sides }\end{array}$ \\
\hline $\begin{array}{l}\text { Deleng yen due angen- } \\
\text { angen } \\
\text { Iki sing di gowo (Kiwo) } \\
\text { Tengen (Antenge angen- } \\
\text { angen) } \\
\text { Podho-Podho }\end{array}$ & $\begin{array}{l}\text { Arms (left and right) } \\
\text { Left Arm } \\
\text { Right Arm }\end{array}$ & $\begin{array}{l}\text { Actions and aims in life } \\
\text { Patience in acting and behaving } \\
\text { All people are created equal, having good sides and } \\
\text { bad sides } \\
\text { Air, source of pure water, part of the god Brahma, } \\
\text { creator of the universe and life }\end{array}$ \\
\hline $\begin{array}{l}\text { Ojo mangan barang kang } \\
\text { petheng) } \\
\text { Kang napak lusi, lan kerikil }\end{array}$ & $\begin{array}{l}\text { Belly } \\
\text { Feet }\end{array}$ & $\begin{array}{l}\text { Prosperity and greed, the source of life } \\
\text { Devotion and respect }\end{array}$ \\
\hline
\end{tabular}

Table 2. Structure of the Wayang. Female

\begin{tabular}{|c|c|c|}
\hline Body Form & Symbol & Interpretation \\
\hline Angger-anggere ono & Nose for breathing & $\begin{array}{l}\text { Concentration in reverence - as a rule, living people } \\
\text { will breathe, and those that cannot breathe will die. } \\
\text { Intellect guides people in their actions. This idea leads } \\
\text { to norms and values in society. } \\
\text { Beauty, fragrance, grandeur, elegance, wisdom }\end{array}$ \\
\hline Isine Wewarah & Head & \\
\hline Katarik ing Sukmo & Hair, Bun, Flower & \\
\hline Ojo Ngugu yen seneng di & Back to the neck & Introspection \\
\hline $\begin{array}{l}\text { Pujimu ojo mung } \\
\text { pendhak) }\end{array}$ & Shoulder & $\begin{array}{l}\text { Self-introspection - people have good and bad sides } \\
\text { Evaluation } \\
\text { Actions and aims in life }\end{array}$ \\
\hline Deleng yen due angen- & Arms (left and right) & Patience in acting and behaving \\
\hline $\begin{array}{l}\text { angen } \\
\text { Iki sing di gowo (Kiwo) }\end{array}$ & Left Arm & $\begin{array}{l}\text { All people are created equal, having good sides and } \\
\text { bad sides }\end{array}$ \\
\hline $\begin{array}{l}\text { Tengen (Antenge angen- } \\
\text { angen) }\end{array}$ & Right Arm & $\begin{array}{l}\text { Air, source of pure water, part of the god Brahma, } \\
\text { creator of the universe and life }\end{array}$ \\
\hline Podho-Podho & Chest (Heart) & \\
\hline Vayudara & & \\
\hline
\end{tabular}




\begin{tabular}{|l|l|l|}
\hline $\begin{array}{l}\text { Ojo mangan barang kang } \\
\text { petheng) } \\
\text { Kang napak lusi, lan kerikil }\end{array}$ & Belly & Prosperity and greed, the source of life \\
& Devotion and respect \\
\hline
\end{tabular}

\section{Structural-Symbolic Analysis of Javanese Society in Wayang Puspasarira}

Fundamentally, Javanese society is a society that holds firm principles in the lives of people. They hold firm to these principles as victuals in the course of life, for which according to Suparlan (1959) there are two primary principles, which are the concept of existence and the placement of people in the universe alongside all its contents and the variety of activities related to the circle of life. These two things concern the concept of "containers" and "fillers", as well as the equilibrium and disorder of elements present in the contents of a container ${ }^{\dagger}$. Several of these concepts can be reflected and modeled in the form of wayang. Because of this, wayang becomes quite important, as it is a part or the ideal reflection of Javanese society.

Although wayang originates from India, the wayang story in Java experienced development or expansion. According to Karts, of the 149 lakon (stories) available, 117 are carangan stories. The creation of carangan stories was adjusted to the condition and situation of the people because the aim of stories is as a means of education and these indirectly act as an effort to provide an understanding of the philosophical elements present in Javanese society (Udasmoro, 1999). As is well-known, at present not only the stories of wayang are undergoing development; the materials and process of making wayang are also experiencing development. One of them is the wayang puspasarira, where forms, materials, and stories adjust to current conditions, though the educational side is not left behind.

Javanese society possesses wealth and a symbol system so perfect that these symbols are even reflected in the everyday lives of its people. Because of this, symbols possess an important role in the cycle of life of Javanese society. Throughout the history of people, symbolism has colored their actions, whether it is their behaviors, languages, or knowledge (Sukanto, 2015). The faces of Javanese people may be reflected through wayang; thus this paper attempts to reveal several parts of the worldview of Javanese society through the creation of wayang puspasarira.

Javanese society essentially possesses a distinct culture. In its cultural system and method, symbols or emblems are used as means to deliver messages of applicable norms or values as the basis for the actions of the people. In this case, symbols can also equalize the set of human knowledge that contains the models used to interpret something as the basis for the actions of people (Syam 2009: 91). As such, symbols can also be delivered as media or facilities to bridge the system of human cognition with the actions of people, where one form of those symbols is language.

Wayang becomes a myth because it contains messages of norms or values that are delivered by and for the people, whether consciously or unconsciously. Meanwhile, structuralism is placed more on revealing hidden messages in the deep structure of the minds of people. Structuralism sees people as being bound to a structure; they always adjust all their actions to the system or structure that holds sway over their lives. According to Drucker, people are seen more as being created for the need for a system or structure. It is through this view of structuralism that the influence of understanding of idealism is formed in the lives of people in Javanese society (Sukanto, 2015: 100-101).

This current study uses the two approaches of symbolism and also structuralism. The structuralism of relations sees symbols, in particular, language, more as relationships to understand the phenomenon of culture. Structuralism sees socio-cultural phenomena such as clothing, foods, myths, rituals, and so on as indications of language, as sentences or texts, which contains certain meanings and creates meaning through articulation (Ahimsa-Putra 2009: 31). Meanwhile, symbolism is used to study and interpret symbols in a visual form that underlies the actions of people.

The lives of people in Javanese society are filled with a variety of believes that contain interrelations among people, nature, and God. This system of relations is usually called as the cosmology of Javanese society. The system contains beliefs of the Jagad alit and Jagad gedhe, which are divided into the three levels of the upper realm, middle realm, and lower realm (Pujianto via Hidajat, 2004). Jagad gedhe is symbolized with the upper realm and Jagad alit is symbolized with the lower realm, while the connector between the upper and lower realms is the middle realm, and the entirety of this becomes a unity in the belief system of Javanese society.

The relations of isor (below) and duwur (above) are classifications that exist in Javanese society (Koentjaraningrat, 1994: 228), which are reflected in various parts of life. For Javanese people, these classifications regard how they view their "living harmony" with God, nature, or fellow people. This term of harmony is also referred by the term Manunggaling Kawulo Gusti, or the union of man and God, and men with other men (Laksono, 2009). In a different discussion related to man with body and soul, Baker (2000: 105) explains that the soul is divided into three parts: the intellectual soul (spiritual, inside the head, above), the sensitive soul (emotions in the chest, middle), and the vegetative soul (belly, below). These viewpoints help to further understand the structure of the body (container) of wayang puspasarira and also function as or possessing meaning (filler) that describes the ideal Javanese person.

The myth of the "above" and "below" can also be seen from the structure of the creation of wayang and in particular puspasarira as one of the models of the ideal picture of a Javanese person. The concept of the "above" and

\footnotetext{
${ }^{\dagger}$ In Abangan, santri, Priyayi. Clifford Geertz.
} 
"below" realms can also be seen from the creation process of wayang puspasarira, where it is connected with the "middle" realm as the realization of harmony, and the connector of the "above" and "below" realms are also symbolized as Budi, Athi, lan Pakarti. This means that culture itself can be related to the three forms of culture, which are Cipta (Reason), Rasa (Feeling), and Karsa (Action) (Koentjaraningrat, 2009).

Table 3. Analysis of Relations and Symbols of Wayang Puspasarira

\begin{tabular}{|c|c|c|c|c|}
\hline & & Relation & Symbol & Interpretation \\
\hline Upper Realm & $\begin{array}{l}\text { Angger-anggere ono } \\
\text { Isine Wewarah } \\
\text { Katarik ing Sukmo }\end{array}$ & Budi (Reason, Idea) & $\begin{array}{l}\text { Nose for breathing } \\
\text { Head } \\
\text { Hair, Bun, Flower }\end{array}$ & $\begin{array}{l}\text { Concentration in } \\
\text { reverence - as a } \\
\text { rule, living people } \\
\text { will breathe, and } \\
\text { those that cannot } \\
\text { breathe will die. } \\
\text { Intellect guides } \\
\text { people in their } \\
\text { actions. This idea } \\
\text { leads to norms and } \\
\text { values in society. } \\
\text { Beauty, fragrance, } \\
\text { grandeur, elegance, } \\
\text { wisdom }\end{array}$ \\
\hline Middle Realm & 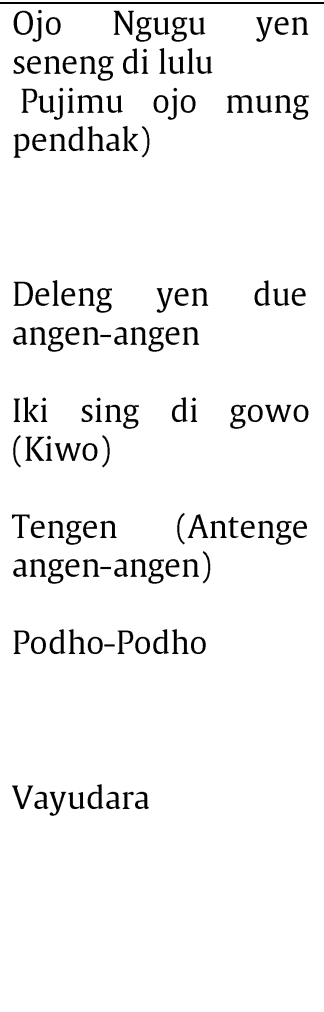 & Athi(Feeling) & $\begin{array}{l}\text { Back to the neck } \\
\text { Shoulder } \\
\text { Arms (left and right) } \\
\text { Left Arm } \\
\text { Right Arm } \\
\text { Chest (Heart) } \\
\text { Breasts }\end{array}$ & $\begin{array}{l}\text { Introspection } \\
\text { Gratefulness for the } \\
\text { blessings of God } \\
\text { Self-introspection - } \\
\text { people have good } \\
\text { and bad sides } \\
\text { Evaluation. } \\
\text { Actions and aims in } \\
\text { life } \\
\text { Patience in acting } \\
\text { and behaving } \\
\text { All people are } \\
\text { created equal, } \\
\text { having good sides } \\
\text { and bad sides } \\
\text { Air, source of pure } \\
\text { water, part of the } \\
\text { god Brahma, creator } \\
\text { of the universe and } \\
\text { life }\end{array}$ \\
\hline Lower Realm & $\begin{array}{l}\text { Ojo mangan barang } \\
\text { kang petheng) } \\
\text { Kang napak lusi, lan } \\
\text { kerikil }\end{array}$ & Karsa (Action) & $\begin{array}{l}\text { Belly } \\
\text { Feet }\end{array}$ & $\begin{array}{l}\text { Prosperity and } \\
\text { greed, the source of } \\
\text { life } \\
\text { Devotion and } \\
\text { respect }\end{array}$ \\
\hline
\end{tabular}

\section{CONCLUSION}

Structural analysis not only presents myths or simply describe mythology, but also shows the role and function of a structural relation. The built-up structure in wayang puspasarira, as well as all its parts, have a role in constructing an identity framework of the wayang and depicts the ideal condition of the society that created it. Here it means that every work of man, to which art is included, certainly possesses its own functions and roles in interpreting culture in an ideal social system for its society. 
Wayang puspasarira presents a new perspective of the depiction of the people of Malang, which are realized in the parts of the wayang. The occurrence of renewal on the visuals of wayang puspasarira also has the setting of cultural phenomena that could be felt, seen, and heard by Mbah Karjo as the artist that created wayang puspasarira. One of the developments of the work of wayang puspasarira is the inclusion of flowers as a very important part to enhance the visuals of wayang puspasarira.

\section{REFERENCES}

Ahimsa-Putra, Heddy Shri. (2009). Strukturalisme Levi-Strauss: Mitos dan Karya Sastra. Yogyakarta Keppel Press Baker, A. (2000). Antropologi Metafisik. Yogyakarta. Kanisius

Geertz, C. (1983). Abangan, Santri, Priyayi. Jakarta. Dunia Pustaka Jaya

Herusatoto, B. (1983). Simbolisme dalam Budaya Jawa. PT Hanindita. Yogyakarta

Hidajat, Robby. (2004). Kajian Strukturalisme Simbol Mitos Jawa pada Motif batik Berunsur Alam. Jurnal Bahasa dan Seni , tahun 32, Nomor 2 tahun 2004

Koentjaraningrat. (1985). Metode-Metode Penelitian Masyarakat. Jakarta: Gramedia.

Laksono, P.M. (2009). Tradisi: Dalam Struktur Masyarakat Jawa Kerajaan dan Pedesaan. Yogyakarta. Kepel Press

Nalan, A. S. (2015). Teater Boneka Sebagai Media Pendidikan Segala Usia Berbasis Budaya disampaikan dalam Seminar Nasional Forum Dosen Indonesia 2015. ISSN: 2460-5271

Polletta, F and M. Jasper, James. (2001). Collective Identity and Social Movements. Annual Review of Sociology. Vol. 27 (2001), pp. 283-305. http://www.jstor.org/stable/2678623.

Soedarsono. R.M. (2010). Seni Pertunjukan Indonesia di Era Globalisasi. Yogyakarta: Gajah Mada University Press.

Syam, N. (2007). Madzab-Madzab Antropologi.Yogyakarta. LKis

Sukanto, O. (2015). Seks Para Pangeran. Yogyakarta. Araska

Suratno, P dan Astiyanto, H. (2005). Gusti Ora Sare 65 Mutiara Nilai Kearifan Budaya Jawa. Yogyakarta: Adiwacana

Udasmoro, W. (1999). Memahami Unconscious Filosofi Jawa Melalui Tokoh Wayang Bima. Jurnal Humaniora, No. 12 SeptemberDesember.

Zahid, S dan Nuriyanti. (2015). "Konservasi Budaya Wayang Suket Melalui Perancangandesain Visual Sebagai Pengembangan Atraksi Budaya Di Desa Wisata Jawa Tengah" disampaikan dalam Seminar Nasional Hasil-Hasil Penelitian dan Pengabdian LPPM

\section{Related Pages:} Universitas Muhammadiyah Purwokerto.

http://elib.unikom.ac.id/files/disk1/703/jbptunikompp-gdl-shintadewi-35126-8-unikom_s-i.pdf

http://sains.kompas.com/read/2013/08/21 / 093344 7/75. Jenis. Wayang. Punah. 